\title{
Objetividad en la cita de referencias
}

Objectivity in citing references

Prof.ADAM NEVILLE

A \& M Neville Engineering

Fecha de recepción: 15-III-2001

REINO UNIDO

\section{PRESENTACIÓN}

Tenemos la suerte de contar en este número especial del 50 aniversario de nuestra revista "Materiales de Construcción" con una colaboración remitida por el Prof. Adam Neville.

El artículo del Prof. Neville, aunque se titula "Objectivity in citing references", encierra mucho más de lo indicado en el título. Es un análisis muy serio -aunque acompañado del buen sentido del humor que caracteriza al autor- que nos debe hacer pensar seriamente como investigadores sobre la objetividad con la que planteamos los resultados de nuestras investigaciones en las publicaciones, bien sean éstas artículos, monografias, ponencias a congresos, etc.

Las opiniones vertidas en este artículo por el Prof. Neville nos deben hacer meditar y yo diría, hacer un verdadero examen de conciencia sobre la objetividad, pues, como él indica, puede ser peligroso, como a veces se suele hacer en determinados sectores de la investigación, decir verdades a medias, pues, a veces, éstas pueden convertirse inmediatamente en mentiras.

El Prof. Adam Neville creo que no precisa presentación pues es conocido universalmente como uno de los "Padres del hormigón", por sus trabajos de investigación, sus publicaciones, especialmente sus libros, entre otros el celebre Properties of Concrete, así como por la escuela de investigadores que supo crear en la Universidad de Leeds (Inglaterra). Los que desde hace ya muchos años nos dedicamos al estudio y mejora de este material sentimos verdadero placer leyendo, en estos últimos tiempos, sus precisas y claras colaboraciones periódicas en la revista Concrete International.

Aunque conocía al Prof. Neville por sus libros, la primera ocasión que tuve de tratarlo personalmente fue con ocasión de la asistencia a dos clases que impartió sobre hormigón en el Instituto Eduardo Torroja, con motivo de un CEMCO, creo que fue en el año 1968, y me quede impresionado de las ideas tan precisas que tenía de los temas y la forma ordenada de exponerlas en un inglés clarísimo.

Siempre he podido comprobar su amabilidad y disponibilidad, como lo ha demostrado en esta ocasión cuando ha tenido la gentileza de responder positivamente a la colaboración que se le había solicitado para nuestra revista.

Prof. M. Fernández Cánovas

Miembro del Comité de Redacción de

Materiales de Construcción

\section{PRESENTATION}

We have the good fortune to include in this special $50^{\text {h }}$ aniversary edition of our journal "Materiales de Construcción" an article sent in by Prof. Adam Neville.

Although the article written by Prof. Neville is entitled "Objectivity in citing references" it has much more to say than is indicated by the title. It is a very serious analysis -although always accompanied by the good sense of humour that characterizes the author- that obliges us to think seriously as investigators about the objectivity with which we present the results of our investigations, whether these are by articles, monographs, lectures or in conferences, etc.

The opinions expressed in this article by Prof. Neville oblige us to meditate upon and, I would say, thoroughly examine our conscience in the relation with the objectivity that we use, since, as he indicates, it can be very dangerous, as often is common practice in some fields of research, to only say half the truth, as, sometimes, this can unintentionally turn into lies.

I do not think that Prof. Adam Neville needs any introduction to his personality, as he is universally known as one of the "Father figures in the history of concrete" for his works on investigation and his publications, especially his books, amongst others the famous Properties of Concrete, as well as the School of Research that he was able to create in the University of Leeds (England). Those of us who are dedicated to the study and improvement of this material take great pleasure reading his precise and clear latest publications in the journal Concrete International.

Although I knew about Prof. Neville through reading his books, the first time that I had the chance to meet him personally was when I attended to two classes that he gave on concrete in the Instituto Eduardo Torroja, at a CEMCO meeting (I think it was in the year 1968). I was impressed by the clarity of his ideas and by his very organised way of expressing them using a very clear English language.

I have always been a witness to his kindness and openess, as again he has shown on this occasion taking the time to reply in a positive way to our request for a publication written by him for our journal.

Prof. M. Fernández Cánovas Member of Board Committee of Materiales de Construcción 


\section{INTRODUCCIÓN}

Es para mí un alto honor poder contribuir a la celebración del cincuenta aniversario de la revista MATERIALESDE CONSTRUCCIÓN. Publicadapor el Instituto Eduardo Torroja, puede considerarse como la continuación del trabajo iniciado por el ingeniero Eduardo Torroja, a quien tuve el gusto de conocer a finales de los años 50. Todavía recuerdo su brillantez y su amabilidad.

La gentil invitación de la Dra. Francisca Puertas Maroto, unida a la también gentil presión ejercida por el Profesor Manuel Fernández Cánovas acabaron por convencerme para que escribiera un breve artículo. Pero, ¿sobre qué tema? Una de las posibilidades podría ser el referirme a algún proyecto experimental, pero este tipo de artículos se publican habitualmente en muchas revistas ofreciendo, por lo general, amplios detalles sobre oscuros ensayos, nuevos, eso sí, pero que no enriquecen nuestros conocimientos. Uno de los comentarios más apropiados a este respecto fue el ralizado por Treval Powers -un gran hombre que explicó el comportamiento del hormigón en términos físicos- el cual, en el año 1968, escribió lo siguiente: "A veces pienso que resulta cuestionable asumir que más experimentación de laboratorio ayude a alcanzar nuestro objetivo, es decir, la fabricación de un hormigón de calidad. Quizá haya llegado el momento de dar mayor prioridad al estudio de la información ya existente"

Los análisis de calidad realizados tiempo atrás, permiten disponer ahora de artículos que forman un "estado del arte", los cuales son normalmente seguidos, años más tarde, por "otra nueva visión" sobre los mismos temas. Por tanto, no pienso que deba contribuir a esa proliferacion de material ya digerido.

Así es que he decidido escribir sobre algo muy diferente: mi opinión personal sobre la objetividad en la selección de referencias que aparecen en algunas publicaciones. Esta decisión podría parecer, en principio, peligrosa, pero no creo que realmente lo sea. Nadie piense que se le está criticando; su amor propio no creo que se lo permitiera. Por lo tanto, puedo estar seguro de que cada uno de mis lectores pensará que lo que escribo no va dirigido a él personalmente, sino a los demás.

\section{2. ¿HASTA QUÉ PUNTO PODEMOS SER OBJETIVOS?}

Antes de hablar de objetividad o de la falta de ella, quiero decir que no soy lo suficientemente inocente como para pensar que es posible alcanzar la objetividad absoluta, incluso en cuanto a la ciencia se refiere.

\section{INTRODUCTION}

$I$ regard it a considerable honour to contribute to the $50^{\text {th }}$ anniversary issue of MATERIALES DE CONSTRUCCIÖN. This journal, being published by Instituto Eduardo Torroja, represents a continuation of work of D. Eduardo Torroja whom I had the pleasure to know in the late 1950s: I still remember his brilliant mind and gentle demeanour.

The charming invitation of Dra. Francisca Puertas Maroto, coupled with the gentle pressure exerted by Professor Manuel Fernández Cánovas, have persuaded me that I should write a brief paper. The question is what kind of paper? One possibility is a report on an experimental project. Such reports are published in numerous journals in prodigious numbers, and they often present detailed data on obscure tests, which are new, but which do not enrich our knowledge. A most apposite comment in this regard was made by Treval Powers -the great man who explained the behaviour of concrete in physical terms- who wrote in 1968: "Sometimes it is questionable, I think, to assume that more laboratory experimentation is the best next step toward that goal [making satisfactory concrete]. Perhaps the time has come to give priority to analysis of information already available".

The early good analyses have now largely given way to state-of-the-art reports, often followed a few years later by the "another-look" variety. I do not think that I should contribute to this proliferation of redigested material.

So I have decided to write something quite different: my personal judgement of objectivity in selecting references in some publications. Mine may seem to be a dangerous endeavour, but I do not expect anyone to imagine that my criticism could possibly apply to him or her; amour propre would not allow this. So I can rest secure in the assumption that every reader will consider anything that I write as applying only to others.

\section{HOWOBJECTIVE CAN WE BE?}

Before commenting on objectivity, or a lack of it, I wish to say that I am not naive enough to believe that absolute objectivity is attainable, even in science. When conducting an experimental investigation, it is 
Cuando se lleva a cabo una investigación experimental, no es sensato utilizar un conjunto arbitrario de condiciones fisicas, dirigir un ensayo y ver cuál es el resultado obtenido. En inglés, la expresión coloquial sería "suck it and see". A este tipo de actuaciones dificilmente se les puede colgar la etiqueta de "investigación". Debemos plantear por lo tanto una hipótesis, y ésta implicará el reșultado que estamos buscando. Asi es que no debe sorprendernos que, a pesar de ser escrupulosamente honestos, persigamos nuestras expectativas quizá con mayor celo del que ponemos para la obtención de otros resultados. Pienso que esto es algo intrínseco a la naturaleza humana: nos sentimos más predispuestos a observar rasgos geniales en nuestros propios hijos que en los de los demás.

Asimismo se plantean problemas mucho más serios cuando los resultados de una investigación vienen condicionados por consideraciones comerciales. Voy a contarles una anécdota al respecto. En los años cincuenta, yo estaba realizando una investigación sobre hormigón fabricado con cemento aluminoso, a fin de establecer la influencia de temperaturas alternativas con distintas intensidades cíclicas sobre la llamada "conversión" del cemento hidratado y la correspondiente pérdida de resistencia en el hormigón. De esta forma pude darme cuenta de que, el efecto de temperaturas más altas de las normales era acumulativo e irreversible, y que las consecuencias resultaban muy significativas para el hormigón que se estaba utilizando. Al ser joven (bueno, reiativamente joven) me sentí muy orgulloso de mi descubrimiento e informé inmediatamente de mi hallazgo al fabricante de cemento aluminoso. Su reacción fue decepcionante para mi ego: "Eso hace tiempo que lo sabiamos", me dijo, "pero no nos interesa darle publicidad". Inocentemente pregunté si no sería buena idea que cada uno de los sacos llevara la indicación de que el cemento que contenían no debía ser utilizado en construcciones expuestas a temperaturas que sobrepararan, períodicamente, los 30 ó $35^{\circ} \mathrm{C}$. La respuesta me dejó boquiabierto, aunque estoy seguro de que, comercialmente, era irreprochable: "Los usuarios potenciales podrían pensar que si el cemento no debe utilizarse en altas temperaturas, tampoco será bueno a temperaturas bajas".

La conclusión final de esta anécdota es que los investigadores que trabajan para una empresa han de ser muy cautos y no publicar resultados perjudicales para ésta. Se trata, en efecto, de un hecho real, y yo no soy tan ingénuo como para enfrentarme a tal situación. Sin embargo, lo que resulta francamente preocupante es que las investigaciones comerciales se publiquen tan sólo en parte; algo totalmente "indeseable" que debería eliminarse por completo. Una información parcial puede conducir al lector a una interpretación not sensible to use an arbitrary set of physical conditions, conduct a test, and see what comes out as a result; the colloquial English description is "suck it and see". Such an approach hardly merits the label "research". We must have a hypothesis, and this implies an outcome that we are looking for. It is not surprising, therefore, that, while scrupulously honest, we look for what we expect with perhaps greater zeal than we observe other outcomes. I believe that this is human nature: you are more likely to discern traits of genius in your own child than in someone else's.

Serious problems arise when research results are assessed from the standpoint of commercial considerations. I will give anecdotal evidence of such an approach. In the 1950s, I was testing concrete made with high-alumina cement in order to establish the influence of alternating temperature with various lengths of temperature cycle upon the so-called "conversion" of the hydrated cement and the associated loss of strength of concrete. I found that the effect of temperature higher than normal was cumulative and irreversible; the consequences of this for concrete in service are significant. Being young (well, relatively young) I was proud of my discovery and I told the manufacturer of high-alumina cement of my finding. His reaction deflated my ego: "we have known this for some time", he said, "but it is not in our interest to publicise this situation". Nalvely, I asked whether it would not be a good idea to state on each cement bag that the cement should not be used in construction likely to experience periods of exposure to temperature above, say, 30 or $35 \mathrm{deg} C$. The answer surprised me, but I am sure it was commercially sound: potential users might think that if the cement is unsuitable at higher temperatures, it may not be all that good even at lower temperatures.

The corollary of this anecdote is that researchers working for a commercial enterprise may be prevented from publishing results harmful to their employer. This is a fact of life, and I am not ingenuous enough to quarrel with such a situation. However, what is worrying is when commercial research is published only in part, anything "undesirable" being screened out. Partial knowledge may lead a reader to misinterpret the true situation because he or she would read the truth but 
errónea de la situación real, ya que él, o ella, creerán estar leyendo la verdad, aunque no sea realmente la auténtica verdad. Para volver al ejemplo anterior sobre cementos aluminosos, si se publica el resultado de un ensayo efectuado, digamos, a $25^{\circ} \mathrm{C}$ (y éste es un hecho consignado), el lector puede que no piense que una temperatura algo superior puede conducir a un resultado signifivamente distinto. Con el paso de los años, he aprendido a fijarme en la procedencia laboral del autor: Universidad, Instituto de investigación, Compañía comercial o Fabricante.

\section{SELECCIÓN DE REFERENCIAS QUE HABLEN SÓLO DE UNO MISMO}

Nadie emprende una investigación sin haber efectuado una revisión exhaustiva de los estudios previos realizados que, normalmente, figuran como "referencias" al final de los artículos. Ocasionalmente todas, o casi todas estas referencias, vienen de los trabajos realizados anteriormente por los propios autores; no se menciona ninguna otra publicación. No quiero señalar a nadie en particular. Incluso es posible que yo haya cometido el mismo fallo en el pasado. Si así fuera, déjenme entonar el "mea culpa".

Mi inquietud se centra, no tanto en la actitud egocéntrica del autor sino en la consecuente falta de objetividad. El trabajo de otros investigadores puede contener diferentes hallazgos y aportar así más luz sobre el asunto en cuestión. La moraleja sería: cuidado con aceptar, sin críticas, los descubrimientos que podemos leer en las revistas, cuando no hacen mención alguna a trabajos realizados por otros investigadores.

\section{OMISION DE REFERENCIAS CONTRADICTORIAS}

Continuando con la utilización selectiva de referencias, me siento en el deber de comentar un nuevo concepto. Lo que voy a describir concierne, una vez más, al cemento aluminoso. No se trata, como podrían pensar algunos, de una idea fija. Nada más lejos de la realidad. Lo cierto es que he realizado una muy amplia investigación con este material. En 1963, publiqué un informe (1) en el que lanzaba una llamada de atención en cuanto a las consecuencias de la "conversión" del cemento hidratado sobre la integridad estructural. Posteriomente, en 1975 y tras haber fallado diversas estructuras en Inglaterra, publiqué un libro titulado: Hormigón de Cemento Aluminoso (2).

Existe, asimismo, una segunda razón para referirme al hormigón de cemento aluminoso que, como todos not the whole truth. To revert to my previous example of high-alumina cement, if results of tests at, say, $25 \mathrm{deg} C$ are reported (and this fact is stated) the reader might not stop to think that a somewhat higher temperature might result in a significantly different behaviour. With increasing age, I have learnt to look at the nature of the author's employment: university, research institute, a trade association, or a manufacturer.

\section{SELECTION OF REFERENCES TO ONESELF ONLY}

Nobody undertakes research without a background of work done earlier, and this is alluded to by way of "references" at the end of the paper. Occasionally all, or nearly all, references are to the current author's earlier work; nobody else's publications are mentioned. I am not pointing a finger at any one in particular, and it is possible that I, too, committed that sin in the past; if so, let me quickly say, mea culpa.

My concern is, not so much with the egocentric attitude of the author, but with the consequent lack of objectivity. The work of other researchers may contain somewhat different findings and may throw a different light on the subject. The moral is: beware of accepting uncritically the findings in papers that do not include any mention of work of other researchers.

\section{OMISSION OF CONTRADICTORY REFERENCES}

Still on the subject of selective use of references, $I$ have come across a different situation. What I wish to describe concerns, once again, high-alumina cement. This is not my "idée fixe" but I did, at one time, undertake a considerable amount of research in that field. Indeed, in 1963, I wrote a paper (1) containing a warning about the consequences of "conversion" of hydrated cement upon structural integrity, and in 1975, after the failure of some structures in England, I published a book under the title High Alumina Cement Concrete (2).

There is a second reason for my referring to highalumina cement concrete. This material was used in 
saben, se utilizó ampliamente en España, ocasionando diversos problemas estructurales que se van resolviendo paulatinamente. Los españoles, por lo tanto, han podido comprobar lo problemática que puede llegar a ser la utilización de cemento aluminoso en la construcción.

Un ejemplo del uso selectivo de referencias que deseo discutir viene dado en uno de los capítulos del libro de Lea: Química del Cemento y del Hormigón (3), titulado "Cementos de aluminato de calcio". Se trata de una nueva forma de denominación del cemento aluminoso, que lo disocia (sin querer hacer un juego de palabras) de un cierto mal reputado "cemento aluminoso .

El capítulo consta de 70 páginas, con 193 referencias que se remontan a más de 100 años atrás. En él se estudian gran cantidad de aspectos del cemento aluminoso, incluso su conversión, no existiendo una sola referencia a mi trabajo. Una de las razones de esto podría ser el que éste fuera de escasa calidad y no mereciera ser mencionado; la verdad es que no me siento calificado para discutir sobre este asunto. También es posible que mi trabajo, relacionado con los efectos deletéreos de la conversión del cemento aluminoso hidratado, no fuera aceptable para aquellos autores que trabajaban para fabricantes de este tipo de cementos.

Con el fin de considerar la segunda posibilidad, consulté la edición original del libro "La Química del Cemento y del Hormigón", escrito por Sir Frederick Lea (4), Director General del "Building Research Station", institución perteneciente a la Administración británica. La tercera edición, publicada en 1970, ya estaba inevitablamente desfasada. Sin embargo, el nuevo libro publicado en 1998 (3), contiene varios capítulos escritos por diferentes autores, aunque ninguno del propio Sir Frederick Lea. En el libro original de este autor (4), donde se hace referencia a mi informe del año 1963, se cita también un contradictorio punto de vista, y dice: "Existe una considerable controversia sobre el efecto a largo plazo de la conservación del hormigón en agua a temperaturas que ronden los $18^{\circ}$, y los datos son discutibles" (4); siendo ésto, precisamente, lo que el lector debe llegar a conocer.

Por considerarlos suficientemente interesantes, tres aspectos de mi trabajo fueron citados en un libro publicado allá por 1962: "Hormigones y cementos con alto contenido de alúmina", de T. D. Robson (5), que era por entonces director de la compañía inglesa que fabricaba este tipo de cemento -empresa que cerró hace algún tiempo-.

Uno de los últimos libros publicados sobre la química del cemento, editado por Bensted and Barnes (6), incluye un capítulo dedicado a los cementos de construction in Spain, and to this day some structural problems are being remedied. So people in Spain are aware of the fact that high-alumina cement in construction may be problematic.

The example of a selective use of references that I wish to discuss is a chapter in Lea 's Chemistry of Cement and Concrete (3) which bears the title "Calcium aluminate cements". This is a new name for high-a!umina cement, which dissociates (no pun intended) it from a certain ill-repute of high-alumina cement.

The chapter is 70 pages long and contains 193 references, going back more than a century. $A$ whole range of aspects of high-alumina cement is discussed, including conversion. There is not a single reference to any of my work. One reason for this could be that my work is of poor quality and cannot by relied upon: I am not qualified to dispute such a point or view. It is also possible that my work, which was concerned with the deleterious effects of conversion of hydrated high-alumina cement, is not palatable to authors working for probably the largest manufacturer of that cement.

To consider the second possibility, I have looked at the original book "The Chemistry of Cement and Concrete" by Sir Frederick Lea (4), formerly Director of Building Research Station, a British government body. The third edition was published in 1970, and has inevitably become out of date; hence, the new book, published in 1998 (3), containing various chapters written by different authors, but of course nothing by the late Sir Frederick Lea. Lea's book(4) makes reference to my 1963 paper. He cites a contradictory view as well, and says: "There has been a considerable controversy on the long-term effect of storage of concrete in water temperatures around $18^{\circ}$ and the data are somewhat conflicting" (4); this is what the reader should be told.

Interestingly enough, three items of my work are cited in a book, published as far back as 1962: "High-alumina cements and concretes", by T. D. Robson (5), who was the director of the company manufacturing high-alumina cement in the United Kingdom; the manufacture ceased some time ago.

The most recent book on the chemistry of cement edited by Bensted and Barnes (6) contains a chapter 
aluminato de calcio, en el cual figuran numerosas referencias a mi trabajo.

Si yo hubiera elaborado la excisión de mi nombre en la referencia $n^{0} 3$ (con perjucio de convertirme en nopersona, según palabras de George Orwell), podría ser acusado, con toda razón, de egocéntrico. Mis apreciaciones son de ámbito general: el autor debería citar aquellas referencias con las que él, o ella, no estuvieran de acuerdo, explicando el porqué. Si está en lo cierto, los lectores aceptarán, con toda seguridad, su punto de vista.

\section{OBJETIVIDAD E INCERTIDUMBRE}

Personalmente yo me inclino por la objetividad, aunque ésta seguramente no garantice la certeza de lo descubierto durante la investigación. El Principio de Heisenberg sobre la incertidumbre, establece la imposibilidad de especificar o determinar simultáneamente, tanto la posición como la velocidad de una partícula. En otras palabras, al realizar las observaciones "desordenamos" aquello que estamos midiendo.

Consecuentemente, sabemos que existen limitaciones inherentes a la precisión con la que podemos observar los fenómenos naturales, y debemos adaptarnos a esta situación sin oscurecer gratuitamente la comprensión de los lectores hacia nuestras investigaciones.

Asimismo, deberíamos evitar escrupulosamente la distorsión de las bases de nuestra investigación por culpa de la inocente selección de referencias basadas en lo que el gran filósofo Bertrand Rusell calificó como: "Un decepcionante soporte de subjetiva certeza"

\section{CONCLUSIONES}

Este breve artículo trata de un par de aspectos objetivos relacionados con la literatura técnica y científica; mis ejemplos podrían parecer poco importantes. Sin embargo creo que, en la actualidad, existe una difusión mucho más amplia sobre temas relacionados con la ciencia. El punto de vista de algunos científicos se ha polarizado fuertemente; por ejemplo, aquéllos que expresan la opinión de que las plantas modificadas genéticamente son beneficiosas para la humanidad, se enfrentan con los que consideran deleznable modificar la naturaleza. Pocos científicos estan dispuestos a ocupar el terreno neutral y reconocer los tres milenios en que las plantas naturales han sido modificadas por el hombre. El debate entre estos dos protagonistas genera mucho calor, pero poca luz. Ciertos científicos son contratados por organizaciones de protesta que les destinan únicamente a difundir la propaganda de sus on calcium aluminate cements, in which there are numerous references to my work.

Were I to elaborate the excision of my name in reference 3 (thus becoming an un-person in George Orwell's parlance) I could be accused of egocentricity, and rightly so. My point is general: an author should cite those references that he or she disagrees with and explain why. If the author is right, the readers will fully accept his views.

\section{OBJECTIVITY AND UNCERTAINTY}

My plea is for objectivity, but this does not guarantee certainty about the findings of research. Heisenberg's Principle of Uncertainty states that it is impossible to specify or determine simultaneously both the position and velocity of a particle. In other words, in making observations, we 'upset' that which we measure.

Consequently, we know that there are inherent limitations to the precision with which we can observe natural phenomena. We have to live with this situation, but we should not gratuitously obscure the reader's understanding of our research. Likewise, we should scrupulously avoid a distortion of the physical background to our research by an innocent selection of references based on what the great philosopher Bertrand Russell called " $a$ delusive support of subjective certainty".

\section{CONCLUSIONS}

This brief paper is concerned with just a couple of aspects of objectivity in technical and scientific literature; my examples may seem unimportant. However, I believe that the broad issue of scientific reliability has recently very much come to the fore. The views of some scientists have become strongly polarized; for example, those who express the opinion that genetically modified plants are beneficial to mankind are opposed by those who see nothing but evil in interference with nature. Few scientists are willing to occupy the middle ground, which would recognise three millennia of man's modification of natural plants. The debate between the two camps of committed protagonists generates much heat, but not light. Some scientists are employed by single-issue protest organizations and simply mouth their employer's propaganda; others 
empresarios; otros trabajan para empresas de desarrollo y venta de nuevas plantas, y no son capaces de entablar debates por el exceso de presión. Todo ello es muy perjudicial para la ciencia, pués arrastra consigo parte de la gloria y reputación de los científicos.

Esta revista se ocupa de los materiales de construcción, materiales que dependen de intereses comerciales. Esto es algo que debemos reconocer. Sin embargo, existe una clara diferencia entre la promoción comercial, por un lado, y las publicaciones de investigación científica y técnica, por otro. Si esta distinción no queda clara, los futuros usuarios de los materiales, quienes los describen y la comunidad de investigadores y técnicos al completo, quedarán desorientados o quizá se sientan engañados. Situaciones de este tipo no prestan un buen servicio a la sociedad. Tampoco serían útiles a científicos, involucrados en algún tipo de investigación por la que hubieran perdido el respeto de la sociedad, siendo tratados, incluso, con desprecio, como meros "matones".

Al parecer estamos a punto de llegar a una situación catastrófica pero, si no olvidamos lo ocurrido en el mundo de los alimentos genéticamente modificados, no llegaremos a meternos en un terreno resbaladizo. Debemos ser, ante todo, muy escrupulosos en la revisión de lo ya publicado, sin pensar si es o no favorable a la tesis del proyecto de investigación; también deberíamos tener en cuenta los importantes trabajos realizados por antiguos investigadores. En otras palabras, debemos ser siempre objetivos. Todo ello redundará en la estima que recibamos de los demás y en la nuestra propia. work for enterprises developing and selling new plants, and may not be able to engage in unhindered debate. All this is not good for science, and it has cost the scientists much of their former reputation and glory.

In this journal, we are concerned with construction materials. These materials involve commercial interests, and this we have to recognise.

Nevertheless, there should be a clear distinction between commercial promotion on the one hand and, on the other, technical, scientific, and research publications. If this distinction is blurred, the users or the various materials, their specifiers, and the entire research and technical community may well become disoriented or even misled. Such a situations would not serve the society at large well. Nor would it serve those involved in research who would lose the respect of the society and might even be treated with contempt as no more than "hired guns."

We are nowhere near such a catastrophic situation but, bearing in mind what has happened in the realm of genetically modified food, we should not start on the slippery slope. The least we can do is to be scrupulous in reviewing literature, regardless of whether or not it is favourable to the thesis of the research project; we should also acknowledge the relevant work of earlier researchers. In other words. at all times, let us be objective. This will be rewarded by the esteem of others as well as by self-esteem.

\section{BIBLIOGRAFÍA}

(1) Neville, A. M.: “A study of deterioration of structural concrete made with high-alumina cement," Proceedings of Institution of Civil Engineers, vol. 25 (julio 1963)pp. 287-324.

(2) Neville, A. M.: High Alumina Cement Concrete, The Construction Press (1975), 201 pp.

(3) Hewlett, P. C. (Ed.): Lea's Chemistry of Cement and Concrete, Arnold (1998). Scrivener, K. L. and Capmas, A.: Calcium aluminate cements, chapter 13 in

(4) Lea, F.M.: The Chemistry of Cement and Concrete. Third Edition, Arnold (1970), 727 pp.

(5) Robson T. D.: High-Alumina Cement and Concrete, Contractors Record \& John Wiley (1962), 263 pp.

(6) Bensted, J. \& Barnes, P. (Eds.): Structure and Performance of Cements, Second Edition, Spon Press (2001).

\section{Nota de Redacción}

El Comité de Redacción agradece a D $\mathrm{D}^{\mathrm{a}}$ Stella Manaut la traducción al español del manuscrito y al Prof. Fernández Cánovas la revisión técnica del mismo. 